\title{
PENERAPAN UU NO. 11 TAHUN 2012 TENTANG SISTEM PERADILAN PIDANA ANAK DI WILAYAH KABUPATEN PAMEKASAN
}

\author{
Umi Supraptiningsih \\ IAIN Madura|umistainpamekasan@gmail.com
}

\begin{abstract}
The problems of children are increasing and increasingly diverse. It causes them to be classified as Children in Conflict with Law $(\mathrm{ABH})$, either as perpetrators or victims. The problems are sexsual crime, theft, scuffelling, mugging, and drug addictive cases. The existance of Law No. I I of 2012 concerning the Act of Children Criminal Justice System (UU-SPPA) in lieu of Law No. 3 of 1997, is expected to give more rights to $\mathrm{ABH}$. UU-SPPA has been implemented as it has been stated in the Act, such as the implementation of Diversification as regulated in the UU-SPPA and also Supreme Court Regulation No. 4 of 2014 concerning Guidelines for the Implementation of Diversity in the Children Criminal Justice System (UU-SPPA). The judges spesialized for Juvenil courts are already available, but the prosecutors and the police are not yet available. During the legal process, $\mathrm{ABH}$ is not detained except in certain cases (ultimum remidium). However, the implementation of the decision cannot be carried out perfectly due to the unavailability of facilities and infrastructure which are mandated by the SPPA, such as vocational training institutions, the Child Welfare Organization (LPKA).
\end{abstract}

Keywords: Implementation, Law No. I I of 2012 concerning the act of Children Criminal Justice System (UU-SPPA)

Abstrak: Permasalahan anak-anak semakin meningkat dan semakin beragam yang menyebabkan mereka tergolong sebagai Anak yang Berhadapan dengan Hukum $(\mathrm{ABH})$ baik anak sebagai pelaku maupun sebagai korban. Mulai dari kasus kejahatan sexsual, pencurian, perkelahian, pencurian, penjambretan sampai kasus narkoba. Lahirnya UU No. I I Tahun 2012 tentang Sistem Peradilan Pidana Anak (UUSPPA) sebagai pengganti UU No. 3 Tahun 1997, diharapkan lebih memberikan hak-hak terhadap $\mathrm{ABH}$. UU-SPPA sudah diterapkan sebagaimana yang menjadi amanah dari UU tersebut, seperti dilaksanakannya Diversi sebagaimana yang telah di atur dalam UU-SPPA dan juga Peraturan Mahkamah Agung No. 4 tahun 2014 tentang 
Pedoman Pelaksanaan Diversi dalam Sistem Peradilan Pidana Anak. Tersedianya hakim anak, namun untuk jaksa dan polisi anak belum tersedia. Selama proses hukum berlangsung $\mathrm{ABH}$ tidak ditahan kecuali pada kasus tertentu (ultimum remidium). Namun pelaksanaan putusan, tidak dapat dilaksanakan dengan sempurna karena belum tersedianya sarana dan prasarana yang menjadi amanah UU-SPPA, seperti lembaga latihan kerja, Lembaga Penyelenggaraan Kesejahteraan Anak (LPKA).

Kata Kunci: Pernerapan, UU No. I I Tahun 2012 tentang Sistem Peradilan Pidana Anak (UU-SPPA)

\section{Pendahuluan}

Kabupaten Pamekasan merupakan salah satu Kabupaten yang berada di Pulau Madura dengan jumlah penduduk 835.101 jiwa yang terdiri dari laki-laki 405.345 jiwa dan perempuan 429.756 jiwa ${ }^{1}$ yang mendiami luas wilayah 792.30 Kilometer persegi, ${ }^{2}$ yang tersebar di 13 (tiga belas) Kecamatan dan 189 Desa/Kelurahan. Dengan data luas wilayah dan jumlah penduduk tersebut, hampir rata-rata permasalahan kenakalan anak-anak atau remaja masih tergolong tinggi dengan beragam kenakalan yang menyebabkan mereka tergolong sebagai Anak yang Berhadapan dengan Hukum (ABH). Ragamnya permasalahan dari kasus kejahatan sexsual, pencurian, perkelahian, pencurian, penjambretan sampai kasus narkoba.

Tantangan yang terberat dalam penyelesaian berbagai kasus tersebut antara lain tidak tersedianya sarana dan prasarana pendukung, alat penegak hukum yang responsive terhadap anak seperti tersedianya penyidik (polisi) anak, jaksa anak dan hakim anak serta pendamping anak atau pekerja sosial.

Lahirnya UU No. 11 Tahun 2012 tentang Sistem Peradilan Pidana Anak (Lembaran Negara RI Tahun 2012 No 153; Tambahan Lembaran Negara RI No. 5332, yang selanjutnya disingkat UUSPPA) sebagai pengganti UU No. 3 Tahun 1997, diharapkan dapat menjadi pencerahan bagi anak-anak yang berhadapan dengan

\footnotetext{
I Sensus Penduduk Tahun 2007, Badan Pusat Statistik Kab. Pamekasan Tahun 2008/2009

${ }^{2}$ Badan Pusat Statistik Kab. Pamekasan Tahun 2008/2009
} 
hukum baik sebagai pelaku ataupun korban untuk tetap dapat memperoleh hak-haknya. Melalui langkah penyelesaian pidana anak dengan menggunakan sistem keadilan restoratif justice yang menjadi tujuan dari UU-SPPA tersebut diharapkan dapat terwujud. Keadilan restoratif justice merupakan bentuk penyelesaian konflik dan berusaha untuk menjelaskan kepada pelaku bahwa perilaku tersebut tidak dapat dibenarkan, kemudian pada saat yang sama juga sebagai langkah untuk mendukung dan menghormati individu. Dengan demikian keadilan restoratif justice yaitu penyelesaian perkara tindak pidana dengan melibatkan pelaku, korban, keluarga pelaku/korban, dan pihak lain yang terkait untuk bersama-sama mencari penyelesaian yang adil dengan menekankan pemulihan kembali pada keadaan semula, dan bukan pembalasan. ${ }^{3}$

Berjalannya waktu pelaksanaan UU-SPPA yang mulai diberlakukan pada 1 Agustus 2014 masih belum cukup sempurna sebagaimana yang menjadi harapan UU-SPPA tersebut, baik sarana dan prasarana pendukung dan alat penegak hukum yang responsive anak. Begitu pula peranan masyarakat yang juga sebagai salah satu faktor penentu keberhasilan asas restoratif justice belum nampak peranannya, masyarakat masih belum memahami tentang anak, masa depan anak dan hak-hak anak yang melekat pada diri anak. Sebagai contoh tidak berhasilnya pelaksanaan Diversi ${ }^{4}$ baik pada tingkat Penyidikan sampai Pengadilan. Pemahaman untuk tetap menghukum pelaku anak dalam penjara yang selalu diharapkan, sebagimana kasus pemerkosaan yang dilakukan oleh HYT $^{5}$, umur 14 tahun, siswa kelas 3 MTs, hakim telah memutus yang bersangkutan dengan tindakan Rehabilitasi di Panti Sosial selama 2 tahun, namun keluarga korban meminta kepada jaksa untuk mengajukan banding karena tidak puas dengan putusan

${ }^{3}$ Pasal I UU No. II Tahun 2012

${ }^{4}$ Diversi : pengalihan penyelesain perkara di luar persidangan

${ }^{5}$ Nama Inisial 
hakim tersebut. ${ }^{6}$ Dalam tulisan ini, permasalah yang akan dibahas meliputi : Penerapan UU No. 11 Tahun 2012 tentang Sistem Peradilan Pidana Anak di Wilayah Kab. Pamekasan dan Faktor pendorong dan penghambat terlaksananya UU No. 11 Tahun 2012 tentang Sistem Peradilan Pidana Anak di Wilayah Kab. Pamekasan.

\section{Metode Penelitian}

Pendekatan yang digunakan dalam penelitian ini, pendekatan kualitatif (qualitative approach) karena data yang dikumpulkan lebih banyak menggunakan data kualitatif yakni data yang disajikan dalam bentuk verbal bukan dalam bentuk angka ${ }^{7}$ yang semaksimal mungkin berusaha mendeskripsikan realitas aslinya untuk kemudian data dimaksud dianalisis dan diabstraksikan dalam bentuk teori sebagai tujuan finalnya. Pada penelitian kualitatif juga ditandai dengan menggunakan metode pengumpulan data yang berupa participant observation dan indepth interview sebagai instrumen pengumpulan data utama. Pendekatan kualitatif yang digunakan bersifat multimetode dalam fokusnya dan menggunakan pendekatan alamiah serta penafsiran terhadap pokok permasalahan yang diteliti. Pemilihan pendekatan ini dianggap tepat karena yang diinginkan peneliti adalah permasalahan dalam setting alamiah dan berusaha untuk memaknai dan menafsirkan fenomena yang ada berdasarkan apa yang dirasakan oleh para informan. Dengan menggunakan pendekatan kualitatif ini diharapkan dapat memperoleh pemahaman yang mendalam dan murni tentang fenomena yang diteliti, dan ini tidak mungkin dapat diperoleh jika tidak menggunakan pendekatan kualitatif.

Selain pendekatan kualitatif yang dipergunakan dalam penelitian ini, peneliti juga menggunakan pendekatanpendekatan dalam penelitian hukum yaitu pendekatan

\footnotetext{
${ }^{6} \mathrm{ABH}$ dampingan peneliti di Pusat Pelayanan Terpadu Pemberdayaan Perlindungan Perempuan dan Anak (PPT P3A) Kab. Pamekasan

${ }^{7}$ Noeng Muhadjir, Metode Penelitian Kualitatif, (Yogyakarta: Rake Sarasin, 1996), 29.
} 
undang-undang (statute approach), pendekatan kasus (case approach), pendekatan historis (historical approach), dan pendekatan konseptual (conceptual approach). ${ }^{8}$

Pendekatan peraturan perundang-undangan (statute approach) digunakan untuk menelaah bentuk dan isi peraturan perundang-undangan yang berkaitan dengan penerapan UUSPPA. Pendekatan studi kasus (case study) dipergunakan untuk menganalisis kasus-kasus yang timbul dimana anak-anak sebagai Anak yang Berhadapan dengan Hukum (ABH). Pendekatan sejarah (historical approach) digunakaan untuk menelaah sejarah tentang perundang-undangan yang dipakai sebagai dasar penjatuhan sanksi terhadap Anak yang Berhadapan dengan Hukum (ABH). Sedangkan pendekatan konsep (conceptual approach) yang digunakan dalam penelitian ini yaitu menelaah konsep-konsep yang berkaitan dengan perlindungan terhadap anak serta realisasi atas hak-hak yang harus diperoleh anak walaupun mereka masuk pada Anak yang Berhadapan dengan Hukum (ABH).

Penelitian ini menggunakan jenis penelitian deskriptif. Penelitian deskriptif adalah untuk memberikan data yang seteliti mungkin tentang manusia, keadaan atau gejala yang lainnya. Metode deskriptif ini dimaksudkan untuk memperoleh gambaran yang baik, jelas, dan dapat memberikan data seteliti mungkin tentang obyek yang diteliti. Dalam hal ini untuk menggambarkan Pelaksanaan UU No. 11 Tahun 2012 tentang Sistem Peradilan Pidana Anak (UU SPPA).

Lokasi penelitian dilakukan di Wilayah Kabupaten Pamekasan. Sumber data dalam penelitian kualitatif adalah kata-kata, dan tindakan. Selebihnya adalah data tambahan seperti dokumen dan lain-lain. ${ }^{9}$ Sumber data dalam penelitian

8 Peter Mahmud Marzuki, Penelitian Hukum (Jakarta : Kencana Prenada Media Group, 2005), 92

${ }^{9}$ Lexy J. Moleong, Metodologi Penelitian Kualitatif, (Bandung: Remaja Rosdakarya, 1990), 112 
ini diperoleh dengan menetapkan sebagai informan penyidik di unit PPA Polres Pamekasan, Jaksa di Kejaksaan Negeri Pamekasan, Hakim di Pengadilan Negeri Pamekasan, Balai Pemasyarakatan Pamekasan, Dinas Sosial Kabupaten Pamekasan dan Lembaga-lembaga terkait yang menangani permasalahan anak.

Dengan teknik pengumpulan data dalam penelitian ini menggunakan (1) Observasi yaitu penggalian data data dengan melakukan pengamatan dan pencatatan dengan sistematik terhadap fenomena-fenomena yang diselidiki ${ }^{10}$. Teknik Observasi ini digunakan untuk mengetahui pelaksanaan UU Sistem Peradilan Pidana Anak di Wilayah Kabupaten Pamekasan. (2) Wawancara, wawancara mendalam (deep interview), maksudnya teknik pengumpulan data dengan cara bertanya secara bebas kepada informan, dengan sebelumnya peneliti telah menyiapkan panduan atau pedoman wawancara yang telah dibuat. Teknik wawancara diperlukan untuk menggali Pelaksanaan UU Sistem Peradilan Pidana Anak di Wilayah Kab. Pamekasan, selanjutnya hasilnya akan terlihat dalam beberapa field notes yang merupakan data untuk selanjutnya dianalisis. (3) Dokumentasi, teknik ini dipergunakan untuk mengumpulkan data tentang kondisi obyektif seperti data sarana dan prasarana, alat penegak hokum, lembaga terkait perlindungan anak dan kasus-kasus anak yang berhadapan dengan hukum baik mereka sebagai pelaku dan korban serta beberapa kasus yang masuk pada lembaga peradilan dan berapa kasus yang dapat diselesaikan dengan menggunakan keadilan restoratif justice.

\section{Pembahasan}

Sistem hukum yang berkembang dan diterapkan di Indonesia adalah sistem hukum yang berasal dari warisan negara jajahan Belanda dan tidak lepas dari pengaruh global sistem

${ }^{10}$ Sutrisno Hadi, Metodologi Research, (Yogyakarta: Andi Affist, 1990), hal., 136 
hukum yang ada di dunia, sehingga bermacam-macam sistem hukum yang diterapkan di lembaga peradilan di Indonesia. Diterapkannya civil law system namun dilain sisi juga diadopsi common law system. Hakim di Indonesia yang satu memakai Undang-undang sebagai dasar putusannya sedangkan hakim lainnya memakai rasa atau keyakinan sebagai dasar keputusannya dan ada pula yang menggunakan hukum adat dan jurisprudensi sebagai satu-satunya acuan untuk mengambil keputusan.

Hal ini sejalan dengan ketentuan dalam UU No. 48 tahun 2009 yang secara jelas menyatakan "bahwa hakim wajib menggali, mengikuti dan memahami nilai yang hidup dalam masyarakat". Ada tiga aliran yang mempengaruhi sistem hukum di dunia peradilan, yaitu (1) aliran legisme atau legal positivism, yang mana hakim berperan hanya melakukan pelaksanaan Undang-undang (Wetstoepassing), (2) aliran freie rechtsbewegung, yang mana hakim bertugas untuk menciptakan hukum (Rechtsschepping) yang tidak terikat dengan Undang-undang, (3) aliran Rechtsvinding, dalam hal mana hakim mempunyai kebebasan yang terikat (gebonden-vrijheid) atau bisa diartikan keterikatan yang bebas (vrije-gebondenheid). ${ }^{11}$

Tiga aliran besar tersebut yang kemudian dapat memberikan pengaruh yang besar, dimana sebenarnya posisi sistem hukum Indonesia. Sistem hukum Indonesia lebih didominasi oleh aliran "Rechtsvinding" atau legal realism dengan cara dan karakteristik budaya Bangsa Indonesia (walaupun tidak ada yang mempertegas). ${ }^{12}$ Indonesia sesungguhnya lebih dekat dengan common law system, hal ini sangat beralasan karena masyarakat Indonesia dan hukum kebiasaan (customary law) begitu bertumbuh kembangnya hidup berakar pinak di masyarakat (living law) yang ada bersama-sama dengan budaya dan agama (terlebih agama Islam) membuat semakin dekat dengan Common Law System ketimbang dengan Roman Law System. ${ }^{13}$

\footnotetext{
" Sabian Utsman, Menuju Penegakan Hukum Responsif, (Yogyakarta: Pustaka Pelajar, 2008), 72

$12 \mathrm{lbid}$

${ }^{13} \mathrm{lbid}, 73$
} 
Penemuan hukum yang kaitannya dengan isu hukum, dalam civil law system yang mengutamakan legislasi sehingga langkah dasar pola nalar yang dikenal sebagai reasoning based on rules adalah penelusuran peraturan perundang-undangan yang dibuat oleh lembaga negara atau pejabat yang berwenang yang isinya mengikat secara umum, langkah ini merupakan langkah pertama dikenal sebagai statute approach. Berikutnya adalah langkah kedua yang mengidentifikasi norma. Rumusan norma merupakan suatu proposisi, sesuai dengan hakekat proposisi, norma terdiri atas rangkaian konsep. Untuk memahami norma harus diawali dengan memahami konsep. Inilah langkah ketiga yang dikenal dengan conceptual approach. ${ }^{14}$

Berkaitan dengan pemidanaan anak, berbagai peraturan dan konvensi telah menempatkan anak-anak yang berhadapan dengan hukum merupakan anak-anak yang harus tetap mendapatkan hak-haknya, bentuk-bentuk penangkapan, penahanan dan pemidanaan adalah upaya hukum terakhir (ultimum remedium), sebagaimana Konvensi Internasional tentang hak-hak anak di dalam pasal 3 menyebutkan bahwa "dalam semua tindakan yang menyangkut anak, baik yang dilakukan oleh lembaga-lembaga kesejahteraan sosial pemerintah atau swasta, lembaga pengadilan, lembaga pemerintah atau badan legislatif, kepentingan terbaik bagi anak harus dijadikan pertimbangan utama bagi kepentingan anak dalam kehidupan dalam lingkup keluarga dan masyarkat".

UU No. 23 Tahun 2002 Jo. UU No. 35 Tahun 2014 tentang Perlindungan Anak secara materiil sudah memberikan perlindungan yang luas terhadap anak-anak tidak terkecuali anakanak yang berhadapan dengan hukum, namun secara formil dalam pelaksanaan UU tersebut masih belum dilaksanakan sebagaimana yang menjadi tujuan UU. Sebagaimana hasil penelitian yang berjudul "Penerapan UU N0. 23 Tahun 2002 Tentang Perlindungan Anak (Studi Kasus Terhadap Anak Yang

\footnotetext{
14 Philipus M. Hadjon dan Tatiek Sri Djatmiati, Argumentasi Hukum, (Yogyakarta: Gajah Mada University Press, 2005), 42-43
} 
Berhadapan Dengan Proses Hukum)", dalam penelitian tersebut memaparkan bahwa penegak hukum belum menerapkan secara menyeluruh ketentuan yang terdapat dalam UU No. 23 Tahun 2002 tentang Perlindungan Anak, baik mulai pada tahap proses penangkapan, penahanan, penyidikan, tuntutan, pemeriksaan di persidangan sampai pada putusan hakim dan kondisi anak-anak di lapas. Penegak hukum mulai dari polisi, jaksa, dan petugas lapas yang belum mempunyai sifat yang sensitif dan responsif anak. Sehingga menyebabkan hak-hak anak serta perlindungan yang harus diberikan kepada anak-anak yang berhadapan dengan proses hukum tidak mereka dapatkan. ${ }^{15}$

Dalam pelaksanaan UU No. 23 Tahun 2002 tentang perlindungan anak, bentuk-bentuk penangkapan, penahanan dan pemidanaan anak adalah hal yang harus menjadikan keputusan terakhir (ultimum remedium), serta diharapkan dalam penanganan kasus-kasus anak yang berhadapan dengan hukum dapat dilakukan Restroaktif justice, sehingga penegak hukum dapat memberikan Diversi.

\section{Peradilan Pidana Anak berdasarkan UU No. 3 Tahun 1997}

UU No. 3 Tahun 1997 tentang Pengadilan Anak yang selama ini dipergunakan sebagai acuan oleh para penegak hukum dalam memeriksa, mengadili dan memutus perkara anak-anak yang berhadapan dengan hukum sudah sangat dirasakan tidak sesuai lagi dengan perkembangan dan kebutuhan hukum masyarakat karena tidak secara komprehensif memberikan perlindungan kepada anak yang berhadapan dengan hukum serta tidak lagi sejalan dengan apa yang menjadi tujuan UU No. 23 Tahun 2002 tentang Perlindungan Anak. Dalam UU No. 3 Tahun 1997 tentang Pengadilan Anak terkait penyebutan Anak nakal didefinisikan, bahwa "anak nakal" adalah anak yang melakukan

\footnotetext{
${ }^{15}$ Umi Supraptiningsih, "Penerapan UU N0. 23 Tahun 2002 Tentang Perlindungan Anak (Studi Kasus Terhadap Anak Yang Berhadapan Dengan Proses Hukum)", Asy-Syir'ah - Jurnal IImu Syari'ah, (Vol 44 No. II, 20I0), Terakreditasi SK No. 43/DIKTI/Kep/2008
} 
tindak pidana atau yang melanggar norma atau kepatutan dalam masyarakat. Sehingga ada suatu kesan yang ditimbulkan dari definisi ini dimana terjadi kriminalisasi terhadap norma-norma dalam masyarakat pada umumnya sehingga perlu kiranya dipikirkan penggunaan istilah anak nakal ${ }^{16}$. Batasan usia anak yang dapat dimintai pertanggungjawabannya telah diputuskan oleh Mahkamah Konstitusi (MK) yang memutuskan bahwa batas bawah usia anak yang bisa dimintai pertanggungjawaban pidana adalah 12 tahun. Sebelum putusan ini, menurut UU No 3 Tahun 1997 tentang Pengadilan Anak, anak yang berusia 8 hingga 18 tahun dapat dimintakan pertanggungjawabannya secara pidana. Dalam putusan MK, menyatakan bahwa :

"frasa 8 tahun dalam Pasal 1 angka 1, Pasal 4 ayat (1), dan Pasal 5 ayat (1) UU Pengadilan Anak berikut penjelasannya bertentangan dengan UUD 1945 dan tidak mempunyai kekuatan hukum mengikat secara bersyarat. Artinya inkonstitusional, kecuali dimaknai 12 tahun,"

Dalam pertimbangannya, MK menyatakan perlu menetapkan batas umur bagi anak untuk melindungi hak konstitusional anak terutama hak terhadap perlindungan dan hak untuk tumbuh dan berkembang. Penetapan usia minimal 12 tahun sebagai ambang batas usia pertanggungjawaban hukum bagi anak telah diterima dalam praktik di berbagai negara.

Usia 12 tahun secara relatif sudah memiliki kecerdasan emosional, mental, dan intelektual yang stabil sesuai psikologi anak dan budaya bangsa Indonesia. Karenanya, batas umur 12 tahun lebih menjamin hak anak untuk tumbuh berkembang dan mendapatkan perlindungan sebagaimana dijamin pasal 28B ayat (2) UUD 1945. Frasa sekurang-kurangnya 8 tahun dalam Pasal 4 ayat (1) dan frasa belum mencapai umur 8 tahun dalam Pasal 5 ayat (1) UU Pengadilan Anak adalah inkonstitusional bersyarat artinya inkonstitusional, kecuali harus dimaknai telah mencapai

${ }^{16}$ Dikutip dari analisis-terhadap-uu-no3-tahun- 1997.html hari Rabu tanggal 28 Agustus 2013 Jam 22.00 WIB 
usia 12 tahun sebagai batas minimum pertanggungjawaban pidana.

Prinsip-prinsip yang terdapat dalam Pengadilan anak berdasarkan ketentuan UU No. 3 Tahun 1997. Pertama Kompetensi Absolut, bahwa Pengadilan anak ada pada Badan Peradilan Umum, artinya Pengadilan anak adalah bagian dari Badan Peradilan Umum baik Pengadilan Negeri maupun Pengadilan Tinggi. ${ }^{17}$ Kedua, bilamana anak-anak melakukan perbuatan pidana bersama-sama dengan orang dewasa baik sipil maupun militer, maka persidangannya harus dipisah. ${ }^{18}$

Asas-asas yang terdapat dalam UU No. 3 Tahun 1997 tentang Pengadilan Anak adalah :

1.Pembatasan umur (pasal 1 butir 1 jo pasal 4 ayat (1) UU No. 3 Tahun 1997) orang yang dapat disidangkan dalam acara pengadilan anak ditentukan secara limitatif yaitu umur 8 tahun dan maksimal berumur 18 tahun dan belum menikah (akan tertapi berdasarkan putusan MK batas bawah usia anak yang bisa dimintai pertanggungjawaban pidana adalah 12 tahun);

2.Ruang lingkup masalah dibatasi: masalah yang diperiksa di sidang Pengadilan Anak hanyalah menyangkut perkara anak nakal saja. Sidang anak hanya berwenang memeriksa perkara pidana, jadi masalah-masalah lain di luar pidana bukan wewenang Pengadilan Anak. Sidang Pengadilan Anak hanya berwenang memeriksa, memutus dan menyelesaikan perkara Anak Nakal (pasal 21 UU No. 3 Tahun 1997).

1) Ditangani Pejabat Khusus, Perkara Anak Nakal ditangani pejabat khusus yaitu Penyidik Anak, Penuntut Umum Anak, dan Hakim Anak;

2) Peran Pembimbing Kemasyarakatan, UU No. 3 Tahun 1997 mengakui peranan pembimbing

\footnotetext{
17 Pasal 2 UU No. 3 Tahun 1997 tentang Pengadilan Anak
}

${ }^{18}$ Pasal 7 UU No. 3 Tahun 1997 tentang Pengadilan Anak 
kemasyarakatan, Pekerja Sosial, dan Pekerja Sosial Relawan;

3) Suasana pemeriksaan dan kekeluargaan. Pemeriksaan perkara di Pengadilan dilakukan dalam suasana kekeluargaan, karena itu hakim, penuntut umum, penyidik, dan penasehat hukum tidak memakai toga.

4) Keharusan Splitsing, anak tidak boleh disidangkan/diadili bersama orang dewasa baik yang berstatus sipil maupun militer;

5) Acara pemeriksaan di Pengadilan Anak dilakukan secara tertutup, dan putusan diucapkan dalam sidang terbuka untuk umum (pasal 153 ayat (3) KUHAP dan pasal 57 ayat (1) UU No. 3 Tahun 1997);

6) Diperiksa oleh hakim tunggal, hakim yang memeriksa perkara di Pengadilan Anak, baik ditingkat pertama, banding atau kasasi dilakukan dengan hakim tunggal. Apabila tindak pidananya diancam dengan pidana penjara di atas 5 (lima) tahun dan pembuktiannya sulit, maka berdasarkan pasal 11 ayat (2) UU No. 3 tahun 1997, perkara diperiksa dengan hakim majelis. Pasal 11 ayat (2) UU No. 3 Tahun 1997 tersebut selain dalam "hal tertentu" yaitu tentang ancamanhukuman dan pembuktian tersebut, juga "dipandang perlu". UU ini tidk menjelaskan yang dimaksud dengan "dipandang perlu"i segi perlindungan anak, dapat diketahui bahwa pasal 11 ayat (2) UU No. 3 Tahun 1997, tidak memberikan perlindungan hukum terhadap anak, karena ketidaktegasan pengaturan tentang kewajiban dengan hakim majelis di dalam pemeriksaan perkara pidana anak. Bisa saja Ketua Pengadilan memandang bahwa perkara tersebut perkara yang tidak sulit pembuktiannya, namun 
kenyataannya sulit, hal ini akan mempengaruhi kualitas perlindungan anak, yang tercermin dari keputusan hakim atas perkara pidana anak. Dalam hal ini anak menjadi korban ketidaktegasan UU No. 3 Tahun 1997 (viktimisasi struktural).

7) Masa penahanan lebih singkat. Masa penahanan terhadap anak lebih singkat yang diatur dalam UU No. 3 Tahun 1997 dibandingkan dengan masa penahanan yang diatur dalam KUHAP. Hal ini memberikan perlindungan terhadap anak, sebab dengan penahanan yang tidak begitu lama, tidak akan berpengaruh besar terhadap perkembangan fisik, mental, dan sosial anak.

8) Hukuman lebih ringan, Hukuman yang dijatuhkan terhadap anak nakal (pasal 22-32 UU No. 3 Tahun 1997), lebih ringan dari ketentuan yang diatur dalam KUHP. Hukuman maksimal terhadap anak nakal adalah 10 tahun. Hal ini juga bila ditinjau dari aspek perlindungan anak, bila bila dibandingkan dengan ketentuan pasal 10 KUHP telah mencerminkan perlindungan terhadap anak. Hakim Pengadilan Anak harus dengan jeli mempertimbangkan dan memahami bahwa penjatuhan pidana terhadap anak-anak merupakan upaya terakhir (ultimum remedium/the last resort). ${ }^{19}$

\section{Peradilan Pidana Anak berdasarkan UU No. 11 Tahun 2012}

Menurut Muhammad Imam Dani Putra landasan filosofis, sosiologis dan yuridis serta kondisi psikopolitik masyarakat yang mendukung perlunya dibuat suatu peraturan perundang${ }^{19}$ Maidin Gultom, Perlindungan Hukum Terhadap Anak, (Bandung : PT. Refika Aditama, 2008),
86-88 
undangan baru tentang Sistem Peradilan Pidana Anak sebagai berikut: dasar filosofis adalah pandangan hidup bangsa Indonesia dalam berbangsa dan bernegara, yaitu Pancasila. Penjabaran nilainilai Pancasila di dalam hukum mencerminkan suatu keadilan, ketertiban, dan kesejahteraan yang diinginkan oleh masyarakat Indonesia terutama anak-anak yang berada di Indonesia.

Landasan sosiologis berupa perwujudan pelaksanaan lembaga peradilan pidana anak dapat menguntungkan atau merugikan mental, fisik, sosial anak. Tindak pidana anak, dewasa ini secara kuantitas dan kualitas cenderung meningkat dibandingkan dengan orang tindak pidana lain, nyaris semua tindak pidana yang dilakukan oleh orang dewasa dilakukan pula oleh anak-anak. Berbagai faktor penyebabnya adalah keadaan sosial ekonomi yang kurang kondusif, pengaruh globalisasi dalam bidang komunikasi dan informasi, hiburan, perkembangan ilmu pengetahuan dan perubahan gaya hidup. Selain hal tersebut masalah ini disebabkan pula oleh faktor intern keluarga seperti kurang perhatian, kasih sayang dan pengawasan dari orang tua, wali atau orang tua asuh terhadap anak sehingga mudah terpengaruh oleh pergaulan yang negatif dilingkungan masyarakat.

Dasar yuridis menurut teori, hukum haruslah membantu manusia berkembang sesuai dengan kodratnya, menjunjung keluhuran martabat manusia, bersifat adil, menjamin kesamaan dan kebebasan, memajukan kepentingan dan kesejahteraan umum.

Dasar psikopolitik masyarakat adalah suatu kondisi nyata di dalam masyarakat mengenai tingkat penerimaan (acceptance) atau tingkat penolakan (resistance) terhadap suatu peraturan perundang-undangan. Tindak pidana yang dilakukan anak baik langsung maupun tidak langsung merupakan suatu akibat dari perbuatan dan tindakan yang dilakukan orang dewasa dalam bersinggungan dengan anak atau merupakan sebagai bagian dalam proses interaksi anak dengan lingkungannya, di mana anak belum mampu secara dewasa menyikapinya. Paradigma ini yang 
harus ditanamkan bagi masyarakat dan aparatur penegak hukum dalam menghadapi anak yang diduga melakukan suatu tindak pidana.

Keikutsertaan masyarakat dalam pembuatan produk hukum akan membangun akseptan dan diharapkan mampu mereduksi serendah mungkin tingkat resistensinya, sehingga akan menjadi produk hukum yang ideal. Keikutsertaan masyarakat dalam proses pembentukannya menjadi faktor penyeimbang dengan komponen pembuat produk hukum lainnya. ${ }^{20}$

Lahirnya Undang-undang No. 11 Tahun 2012 tentang Sistem Peradilan Pidana Anak (Lembaran Negara RI Tahun 2012 No 153 Tambahan Lembaran Negara RI No. 5332, selanjutnya disingkat UU-SPPA) pada tanggal 30 Juli 2012 merupakan UU yang diharapkan dapat memberikan perlindungan kepada anakanak yang berhadapan dengan hukum. Pengesahan UU-SPPA merupakan langkah maju dalam penanganan anak yang berhadapan dengan hukum, yang mana UU tersebut setidaknya telah memperbaiki sejumlah hal dari tujuh kelemahan dalam UU No 3 Tahun 1997 tentang Pengadilan Anak. Asas yang paling mendasar dalam UU-SPPA adalah keadilan restorative (restroaktif justice) yang selanjutnya penegak hukum dapat melakukan Diversi.

Dengan mengedepankan musyawarah mufakat dengan cara pemulihan kerugian yang dialami korban dan pelaku lebih dikedepankan daripada hukuman penjara. Hukuman yang diterapkan terhadap anak yang berhadapan dengan hukum bertujuan mendidik, memberikan pembinaan dan bukan ajang membalas dendam, upaya yang demikian difasilitasi oleh Negara melalui penegak hukum.

UU-SPPA mengadopsi sistem diversi artinya penyelesaian kasus secara kekeluargaan di luar pengadilan lebih diutamakan daripada proses peradilan atau mengalihkan proses pidana dalam persidangan menjadi diluar persidangan. Penegak hukum nanti

${ }^{20}$ Dikutip dari analisis-terhadap-uu-no3-tahun- 1997.html hari Rabu tanggal 28 Agustus 2013 Jam 22.00 WIB 
akan memperoleh ruang lebih besar untuk mendamaikan dua pihak berperkara yang salah satu atau dua pihak adalah anak-anak yang melakukan pelanggaran hukum dengan ancaman hukuman kurang dari tujuh tahun dan bukan merupakan pengulangan tindak pidana..21 Upaya diversi wajib dilakukan pada tingkat penyidikan, penuntutan, dan pemeriksaan perkara anak di Pengadilan negeri. Sehingga yang sangat berperan sebagai mediator dalam diversi adalah penyidik polisi, jaksa penuntut umum dan hakim. Bila pada tahap penyidikan tidak berhasil, maka jaksa sebagai penuntut umum wajib melakukan diversi, bila tidak berhasil, maka hakimpun wajib melakukan upaya diversi dimaksud ${ }^{22}$. Selama anak-anak menjalani proses peradilan, maka anak-anak tersebut diletakkan di Lembaga Penempatan Anak Sementara (LPAS). Bila Diversi tidak berhasil atau kesepakatan diversi tidak dilaksanakan, maka proses pengadilan anak dilanjutkan.

Polisi, jaksa dan hakim yang melaksanakan penyidikan, penuntutan dan pemeriksaan adalah penyidik anak, penuntut umum anak, dan hakim anak, termasuk pula hakim banding anak dan hakim kasasi anak. Dalam ketentuan pasal 92 ayat (1) menyebutkan bahwa pemerintah wajib menyelenggarakan pendidikan dan pelatihan bagi penegak hukum dan pihak terkait secara terpadu, hal ini dimaksudkan bahwa para penegak hukum adalah mereka yang secara profesional adalah penegak hukum yang mempunyai sensitifitas terhadap anak-anak.

Berlakunya UU-SPPA mengupayakan tidak ada lagi bentuk-bentuk menahan anak di rumah tahanan seperti sekarang, penyidik nanti mengupayakan dua pihak melakukan perdamaian dengan atau tanpa ganti rugi, hukuman berupa penyerahan anak kembali ke orangtua, hukuman berupa pelayanan masyarakat, atau penyerahan ke lembaga pendidikan.

\footnotetext{
21 Pasal 7 UU-SPPA

22 Bagaimana mekanisme dan pelaksanaan diversi akan diatur lebih lanjut dengan Peraturan Pemerintah (pasal I 5 UU-SPPA)
} 
Begitu pula pengaturan batasan minimal anak yang bisa dimintai pertanggungjawaban hukum pidana dari awalnya delapan tahun menjadi duabelas tahun sampai delapan belas tahun $^{23}$ (sejalan dengan putusan MK No. 1/PUU-VIII/2010). Sementara itu, batasan minimal anak yang bisa ditahan adalah empat belas sampai delapan belas tahun ${ }^{24}$.

Beberapa perangkat hukum harus dipersiapkan dalam rangka memberlakukan UU-SPPA, baik secara fisik maupun non fisik. Secara Fisik meliputi meliputi Lembaga Pembinaan Khusus Anak (LPKA) adalah lembaga atau tempat anak menjalani masa pidananya, Lembaga Penempatan Anak Sementara (LPAS) adalah tempat sementara bagi anak selama proses peradilan berlangsung, Lembaga Penyelenggara Kesejahteraan Sosial (LPKS) adalah lembaga atau tempat pelayanan sosial yang melaksanakan penyelenggaraan kesejahteraan sosial bagi anak, ruang khusus penyidikan anak yang bernuansa anak-anak, ruang tunggu khusus sementara menunggu persidangan, kebutuhan tersebut sudah harus ada seiring berlakunya UU-SPPA. Sedangkan kebutuhan non fisik meliputi ketersediaan Sumber Daya Manusia yang meliputi perangkat hukum yang telah terdidik dan memiliki sensitifitas terhadap anak yaitu penyidik anak, jaksa anak dan hakim anak. Begitu pula didukung dengan tersedianya pembimbing kemasyarakatan, pekerja sosial profesional, tenaga kesejahteraan sosial, dan pendamping yang betul-betul dapat memberikan perlindungan terhadap anak-anak yang berada dalam kasus hukum. Terpenuhinya kebutuhan fisik dan non fisik dalam pasal 105 UU-SPPA diberi tenggang waktu 5 (lima) tahun.

Penerapan UU No. 11 Tahun 2012 tentang Sistem Peradilan Pidana Anak

Hasil penelitian dari tiga institusi penegak hukum yaitu penyidik kepolisian, jaksa penuntut umum dan hakim di

\footnotetext{
23 Pasal 21 UU-SPPA

${ }^{24}$ Pasal 32 ayat (2a) UU-SPPA
} 
Pengadilan Negeri Pamekasan, Pembimbing Kemasyarakatan Balai Pemasyarakatan Pamekasan dan Dinas Sosial Kabupaten Pamekasan, Dapat dilakukan pembahasan dan Analisa sebagai berikut. Bahwa penerapan UU No. 11 Tahun 2012 tentang Sistem Peradilan Pidana Anak sudah diterapkan sebagaimana yang menjadi amanah dari UU-SPPA tersebut.

Pertama, Dilaksanakannya Diversi sebagaimana yang telah di atur dalam UU-SPPA dan juga Peraturan Mahkamah Agung No. 4 tahun 2014 tentang Pedoman Pelaksanaan Diversi dalam Sistem Peradilan Pidana Anak. Mulai dari tingkat penyidikan, penyidik wajib melakukan Diversi dengan ketentuan $\mathrm{ABH}$ berumur 12 tahun tetapi belum berumur 18 tahun atau telah berumur 12 tahun meskipun pernah kawin tetapi belum berumur 18 tahun, $\mathrm{ABH}$ didakwa melakukan tindak pidana yang diancam dengan pidana penjara dibawah 7 tahun. ${ }^{25}$ Bilamana dalam tingkat penyidikan tidak berhasil, maka harus dilanjutkan pada tingkat penuntutan. Jaksa juga wajib melakukan diversi, jika tidak berhasilpun, maka hakim di tingkat Pengadilan Negeri juga wajib menggelar diversi. Jika dalam proses diversi tidak menghasilkan kesepakatan atau kesepakatan diversi tidak dilaksanakan, maka Proses peradilan pidana Anak dilanjutkan. Proses diversi yang selalu melibatkan $\mathrm{ABH}$ dan orangtuanya, korban, penyidik, pembimbing kemasyarakatan, kepala desa/tokoh masyarakat, PPTP3A selama tahun 2015 sampai 2017 telah melaksanakan 15 kali diversi, dari 15 tersebut yang sampai terjadi kesepakatan 9 kasus, 1 kasus berhasil diversi tapi oleh pengadilan tidak diterbitkan penetapan, yang 5 kasus lanjut sampai putusan Pengadilan dan rata-rata putusan Pengadilan dikembalikan pada orang tua $\mathrm{ABH}$.

Kedua, selama proses hukum berlangsung $\mathrm{ABH}$ tidak ditahan namun diserahkan kepada orang tua, jika orang tua tidak bersedia atau mengingat kondusifitas masyarakat lingkungan $\mathrm{ABH}$ tidak bisa menjamin keselamatan $\mathrm{ABH}$, maka $\mathrm{ABH}$

${ }^{25}$ Pasal 2 dan 3 Perma No. 4 Tahun 2014 
diamankan di Polres atau Polsek. Sejak berlakunya UU-SPPA tidak pernah $\mathrm{ABH}$ dilakukan penahanan, hal ini sejalan dengan ketentuan pasal 16 ayat (3) UU No. 23 Tahun 2002 tentang Perlindungan anak yang menyatakan bahwa "penangkapan, penahanan atau tindak pidana penjara anak hanya dilakukan apabila sesuai dengan hukum yang berlaku dan hanya dapat dilakukan sebagai upaya terakhir".

Memang tidak sesederhana apa yang tersirat dalam UU dan peraturan pelaksananya, beberapa persoalan muncul dilapangan, penyidik dan jaksa tidak melakukan penahanan selama proses hukum yang seharusnya $\mathrm{ABH}$ dapat ditempatkan pada Lembaga Penempatan Anak Sementara (LPAS) atau Lembaga Penyelenggaraan Kesejahteraan Sosial (LPKS) selama LPAS atau LPKS belum tersedia, maka atas kesepakatan Kementerian Hukum dan HAM dengan Kementerian Sosial, ABH ditempatkan di Wisma Anak yang berada di Lembaga Pemasyarakatan. Hal ini yang tidak pernah terealisasi karena wajah Wisma Anak tersebut masih belum bisa dihilangkan dari kesan penjara atau jeruji sehingga Pendamping Sosial dan PPTP3A selalu keberatan. Problem di masyarakat juga tidak sederhana, seperti $\mathrm{ABH}$ Herly, 16 tahun, masyarakat lingkungan tempat tinggal $\mathrm{ABH}$ tidak bersedia menerima $\mathrm{ABH}$ pulang ke rumahnya, sehingga atas kesepakatan penyidik dan orang tua $\mathrm{ABH}$ sementara diamankan di polres, sedangkan Polres tidak memiliki sarana yang memadai untuk tempat tinggal $\mathrm{ABH}$, tidak sebentar $\mathrm{ABH}$ berada di Polres kurang lebih 3 bulan. Begitu pula yang sekarang ini dialami oleh $\mathrm{ABH}$ Lubna, 16 tahun, upaya diversi sudah dilakukan namun tidak ada kesepakatan karena korban meminta penggantian motor yang dihilangkan $\mathrm{ABH}$, saat $\mathrm{ABH}$ diputuskan untuk dikembalikan kepada orang tuanya namun orang tuanya tidak sanggup mengasuh, ini problem yang tidak sederhana sehingga selama ini ABH berada di Polsek.

Ketiga, Pelaksanaan putusan hakim sulit untuk diterapkan karena lembaga yang seharusnya sudah ada dan siap untuk 
menerima $\mathrm{ABH}$ ternyata belum terbentuk, seperti lembaga latihan kerja yang ada di Kabupaten Pamekasan belum ada, Lembaga Penyelenggaraan Kesejahteraan Anak (LPKA), dimana anak-anak yang perlu mendapatkan rehabilitasi dapat ditempatkan pada LPKA. Seringnya terjadi putusan hakim tidak dapat dilaksanakan dengan sempurna. Sebagaimana hakim memutuskan Rehabilitasi di Panti Sosial dan Rehab milik Dinas Sosial Propinsi Jawa Timur di Pamekasan selama 2 tahun, namun Panti Sosial tidak bisa melaksanakan dengan waktu 2 tahun karena program yang ada adalah latihan kerja selama 6 bulan. Mengingat kondisi seperti ini, kerjasama antara kejaksaan dan PPTP3A, untuk mengisi sisa waktu maka $\mathrm{ABH}$ dilakukan rehabilitasi di Pondok Pesantren yang dapat dipercaya dan menjadi rujukan.

Faktor yang mendorong dan menghambat terlaksananya UU No. 11 Tahun 2012 tentang Sistem Peradilan Pidana Anak

Faktor pendorong penerapan UU-SPPA di wilayah Kab. Pamekasan, dapat dijabarkan sebagai berikut : Pertama, tersedianya alat penegak hukum yang bersertipikat (hakim anak bersertifikat) walaupun itu masih terbatas hakim sedangkan untuk penyidik dan jaksa belum ada, sehingga dalam waktu yang tidak lama untuk betul-betul memenuhi apa yang menjadi amanah UUSPPA Kementerian Hukum dan HAM harus segera melakukan Pendidikan dan pelatihan bagi penyidik dan jaksa. Sebagaimana yang menjadi amanah dalam pasal 26 UU-SPPA. Kedua, pemahaman penyidik dan jaksa sebagian besar sudah memahami tentang amanah yang terdapat dalam UU-SPPA, termasuk hukum acara yang diterapkan bagi $\mathrm{ABH}$.

Faktor penghambat penerapan UU-SPPA, pertama dipengaruhi adanya pemahaman masyarakat yang masih minim tentang perlindungan anak dan pemahaman tentang UU-SPPA, dan pola pikir Sumber Daya Manusia yang masih lama. Pola pikir masyarakat masih menganggap bahwa anak-anak adalah orang yang sama sehingga jika melakukan perbuatan pidana maka harus mempertanggung jawabkan perbuatannya dengan menjalani 
proses hukum dan dipidana. Masyarakat belum memahami betul tentang keberadaan UU No. 23 Tahun 2002 Jo. UU No. 35 Tahun 2014 tentang Perlindungan Anak, anak pelaku sebenarnya juga anak yang menjadi korban baik itu korban dari orang tua ataupun korban dari lingkungan. Hal inilah yang kemudian menyebabkan proses diversi jarang berhasil, korban inginnya menghukum anak sebagaimana layaknya pelaku orang dewasa. Untuk melakukan Analisa problem ini tepatlah dipergunakan teori dari Roscoe Pound Roscoe Poud, bahwa hukum : "Law is a tool of a social engineering", adalah persis sama seperti apa yang dikatakan oleh Mochtar Kusumaatmadja bahwa hukum itu merubah masyarakat. Fungsi hukum menurut Roscoe Poud tidak hanya berfungsi mengatur, tetapi juga harus berfungsi membangun masyarakat. Bilamana dilihat dari perspektif politik hukum, maka hukum berasal dari atas ke bawah (top down) maksudnya disini adalah hukum itu berasal dari pemerintah untuk dijalankan oleh masyarakat karena hukum butuh regulasi dari pemerintah. Teori Roscoe Poud ini yang pada kenyataannya saat ini diterapkan dalam pembentukan hukum di Indonesia, yaitu kurangnya inisiatif DPR dalam mengajukan RUU yang mementingkan kepentingan masyarakat.

Kedua, Faktor penghambat dalam penerapan UU-SPPA juga dipengaruhi ketidak tersedianya sarana dan prasarana, hal ini disebabkan dari Sumber Dana untuk memenuhi sarana dan prasarana tersebut yang belum ada dan dukungan dari pemerintah daerah juga belum nampak. Begitu pula Dinas Sosial Kab. Pamekasan yang sangat muda usianya, belum genap 1 tahun karena baru pisah dengan Dinas Sosial dan Tenaga Kerja, sehingga programnya masih melanjutkan program dari Dinas Sosial dan Tenaga Kerja.

\section{Penutup}

UU-SPPA sudah diterapkan sebagaimana yang menjadi amanah dari UU-SPPA, yaitu dilaksanakannya Diversi 
sebagaimana yang telah di atur dalam UU-SPPA dan juga Peraturan Mahkamah Agung No. 4 tahun 2014 tentang Pedoman Pelaksanaan Diversi dalam Sistem Peradilan Pidana Anak. Mulai dari tingkat penyidikan, penuntutan dan pengadilan; selama proses hukum berlangsung $\mathrm{ABH}$ tidak ditahan namun diserahkan kepada orang tua, jika orang tua tidak bersedia atau mengingat kondusifitas masyarakat lingkungan $\mathrm{ABH}$ tidak bisa memberikan jaminan perlindungan terhadap $\mathrm{ABH}$, maka $\mathrm{ABH}$ diamankan di Polres atau Polsek. Sejak berlakunya UU-SPPA tidak pernah ABH dilakukan penahanan, hal ini sejalan dengan ketentuan pasal 16 ayat (3) UU No. 23 Tahun 2002 tentang Perlindungan anak dan ketentuan pasal 30 UU-SPPA; pelaksanaan putusan hakim tidak dilaksanakan dengan sempurna karena lembaga yang seharusnya sudah ada dan siap untuk menerima $\mathrm{ABH}$ ternyata belum terbentuk, seperti lembaga latihan kerja, Lembaga Penyelenggaraan Kesejahteraan Anak (LPKA).

Faktor pendorong penerapan UU-SPPA di wilayah Kab. Pamekasan : tersedianya alat penegak hukum yang bersertipikat (hakim anak bersertifikat) walaupun itu masih terbatas hakim sedangkan untuk penyidik dan jaksa belum ada, dan pemahaman alat penegak hukum atas UU-SPPA beserta hukum acaranya. Sedangkan faktor penghabat penerapan UU-SPPA adanya pemahaman masyarakat yang masih minim tentang perlindungan anak dan pemahaman tentang UU-SPPA, dan pola pikir Sumber Daya Manusia yang masih lama; ketidak tersedianya sarana dan prasarana sebagaima amanah dari UU-SPPA.

\section{Daftar Pustaka}

Amalia Nugraheni, Novie, Sistem Pemidanaan Edukatif Terhadap Anak Sebagai Pelaku Tindak Pidana, Tesis Program Pascasarjana Ilmu Hukum Universitas Diponegoro Semerang, (10 Desember 2009)

Gultom, Maidin, Perlindungan Hukum Terhadap Anak, Bandung : PT. Refika Aditama, 2008. 
Hadi, Sutrisno, Metodologi Research, Yogyakarta: Andi Affist, 1990 J. Moleong, Lexy, Metodologi Penelitian Kualitatif, Bandung: Remaja Rosdakarya, 1990.

M. Hadjon, Philipus, dan Tatiek Sri Djatmiati, Argumentasi Hukum, Yogyakarta: Gajah Mada University Press, 2005

Marzuki, Peter Mahmud, Penelitian Hukum ,Jakarta : Kencana Prenada Media Group, 2005, Spradley, J.P. Participant Observation. New York: Holt, Rinehart, and Winston,1980

Muhadjir, Noeng, Metode Penelitian Kualitatif, Yogyakarta: Rake Sarasin, 1996.

Nonet, Phillippe dan Philip Selznick, Hukum Responsif, diterjemahkan dari Law and Society in Transilition oleh Raisul Muttaqien, Bandung : Nusamedia, 2007

Rahardjo, Satjipto, Hukum Progresif - Sebuah Sintesa Hukum Indonesia, Yogyakarta: Genta Publishing, 2009.

Soekamto, Soerjono, Pengantar Penelitian Hukum, Jakarta : UI Press, 1988.

Spradley, J.P. Participant Observation. New York: Holt, Rinehart, and Winston, 1980.

Supraptiningsih , Umi, Penerapan UU N0. 23 Tahun 2002 Tentang Perlindungan Anak (Studi Kasus Terhadap Anak Yang Berhadapan Dengan Proses Hukum)", Asy-Syir'ah - Jurnal Ilmu Syari'ah , (Vol 44 No. II, 2010), Terakreditasi SK No. 43/DIKTI/Kep/2008

Supraptiningsih, Umi. "Kesiapan Penegak Hukum Di Kabupaten Pamekasan Dalam Pemberlakuan UU No. 11 Tahun 2012 Tentang Sistem Peradilan Pidana Anak." (2014).

Sutatiek, Sri, "Politik Hukum UU No. 11 Tahun 2012 tentang Sistem Peradilan Pidana Anak", Varia Peradilan, No. 328 (Maret, 2013)

Sensus Penduduk Tahun 2007, Badan Pusat Statistik Kab. Pamekasan Tahun 2008/2009

Utsman, Sabian, Menuju Penegakan Hukum Responsif, Yogyakarta: Pustaka Pelajar, 2008. 